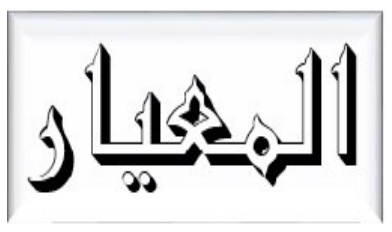

Al Mi'yar

Vol. 2, No. 2, Oktober 2019

P-ISSN: 2620-6749, E-ISSN: 2620-6536

DOI: $10.35931 / a m . v 2 i 2.123$

\title{
PSIKOLINGUISTIK DALAM METODOLOGI PEMBELAJARAN BAHASA ARAB DI ERA POSTMETODE
}

\author{
Muhammad Yusuf \\ Universitas Islam Negeri Sunan Kalijaga, Yogyakarta, Indonesia \\ Email: elyusuf03@gmail.com
}

\begin{abstract}
ABSTRAK
This paper aims to present the theory of psycholinguistics as a basis for developing the methodology of learning Arabic in the post methods era. This study encouraged by the emergence of new trends related to the Arabic learning methodology. In this trend, the methodology was formulated based on academic readings from various perspectives, one of which is psycholinguistics. This paper relies on bibliographic sources in the form of books and articles (literature studies) that are in scientific journals related to the subject matter. Reading the data of thought by academics using a critically constructive approach and meaning of the substance using content analysis. Based on the studies that have been conducted, in the context of post methods, the psycholinguistic theory was seen as a building that used as a foundation in developing learning models. Where in this era is marked by the reduction of the role of methods in language learning? The learning model that was born based on this assumption is active, cooperative learning, and (pakem) learning. Furthermore, in applying this model, the teacher is required to play an optimal role. The integral form, the teacher is required to have personal competence, social competence, and professional competence. This study has a significant urgency considering the post-method trend is a formula that results from the academic reading of a psycholinguistic-based teacher to utilize learning activities in the classroom.
\end{abstract}

Keywords: Psycholinguistics, Arabic Language Learning Methodology, Postmethod

\section{PENDAHULUAN}

Pendekatan dan metode sampai sejauh ini dianggap sebagai sejoli yang tidak terpisahkan dalam proses pembelajaran bahasa. Secara fungsional, keduanya merupakan formula yang diupayakan untuk mengoptimalkan efektifitas pembelajaran bahasa. Kendati demikian, keduanya tidak bersifat absolut. Dalam narasi Syakur bahwa tidak ada satupun pendekatan, pun 
Muhammad Yusuf: Psikolinguistik Dalam Metodologi Pembelajaran Bahasa Arab Di Era Postmetode

metode, yang dapat menjamin keberhasilan di dalam pembelajaran bahasa. Tidak ada satupun metode yang compatible untuk semua situasi dan kondisi dalam proses pembelajaran bahasa yang multikompleks. Dengan kata lain, setiap pendekatan, pun metode, mempunyai kekurangan. ${ }^{1}$ Sebagai konsekuensi logis dari kekurangan pendekatan dan metode tersebut, proses pembelajaran bahasapun belum berjalan optimal.

Dalam upaya merespon kekurangan tersebut, telah banyak para akademisi yang mencoba menawarkan solusi dengan harapan dapat meminimalisir, bila memungkinkan menafikan, kesenjangan dalam proses pembelajaran bahasa. Upaya tersebut antara lain: 1) eklektisasi metode pembelajaran bahasa dengan mengkombinasikan satu metode tertentu dengan metode yang lain ${ }^{2}$; 2) menkonstruksi setiap kelebihan yang meliputi suatu pendekatan dan metode pembelajaran bahasa ${ }^{3}$; 3) mengalihkan perhatian dari pencarian pendekatan dan metode komprehensif kedalam pencarian silabus-silabus yang dianggap lebih fleksibel bila dijumpai suatu kekurangan. ${ }^{4}$

Dalam konteks bahasa Arab, formulasi akademisi tersebut nampaknya belum bersifat solutif. Hal itu salah satu faktornya dikarenakan konstruksi gagasan para akademisi masih terbatasi pada hirarki metodologi ala Antony yang terdiri dari pendekatan, metode, dan tekhik dalam pembelajaran. Konsep ini terkesan terlalu mendewakan metode dan terkesan menegasikan peran faktor lain dalam proses pembelajaran. Sehingga bisa diasumsikan konsep ini kurang adaptable untuk diimplementasikan dalam proses pembelajaran bahasa Arab saat ini. Berbeda halnya dengan bahasa Inggris misalnya, yang telah mendengungkan narasi baru berkaitan dengan metodologi pembelajarannya. Narasi tersebut terbingkai dalam terma postmetode. Dalam terma ini, aspek efektifitas dan efesiensi dalam proses pembelajaran bahasa lebih dilihat secara proporsional, dan tidak berkutat pada persoalan metode

\footnotetext{
${ }^{1}$ Nazri Syakur, Kognitivisme Dalam Metodologi Pembelajaran Bahasa (Yogyakarta: PT Pustaka Insan Madani, 2009), h. 1-2.

2 Output dari upaya ini seperti penggabungan metode langsung dan metode gramatika-terjemah menjadi metode eklektik. Lihat dalam Nazri Syakur, .... 2.

${ }^{3}$ Output dari upaya ini pada gilirannya dikenal dengan istilah metode elektik.

4 Output dari upaya ini antara lain: silabus gramatikal, situasional, komunikatif, gramatikal-situasional, situasional-komunikatif, gramatika-komunikatif, dan sebagainya.
} 
Muhammad Yusuf: Psikolinguistik Dalam Metodologi Pembelajaran Bahasa Arab Di Era Postmetode

pembelajaran semata. Namun juga memasukkan aspek lain seperti profesionalitas guru dalam menahkodai proses pembelajaran. ${ }^{5}$ Fakta ini semakin mengejawantahkan tertinggalnya bahasa Arab dari bahasa Inggris dalam konteks metodologi pembelajarannya.

Dalam kaitan tersebut, agaknya merekonstruksi metodologi pembelajaran bahasa Arab dengan mengimpresikannya kedalam konteks postmetode menjadi salah satu gagasan yang perlu dinarasikan. Dalam konteks ini, rumusan metodologi pembelajaran bahasa Arab harus merupakan hasil dari dialektika antardisipliner keilmuan, salah satunya hasil dialog ilmu linguistik dan psikologi atau yang lebih lazim dengan istilah psikolinguistik. Peran psikolinguistik dalam pembelajaran bahasa sangat penting mengingat pembelajaran bahasa juga berarti mencakup kegiatan berbahasa. Sementara kegiatan berbahasa tidak berhenti pada wilayah mekanistik, namun juga melibatkan wilayah mentalistik. ${ }^{6}$ Senada dengan hal tersebut, Syahid berpendapat bahwa psikolinguistik dalam pembelajaran bahasa bagi nonnative berperan dalam mengidentifikasi bagaimana bahasa itu dan bagaimana seorang pembelajar memperoleh bahasa, lalu mengekspresikannya dalam tindak komunikasi.7 Sementara dalam perspektif Zulhannan, bahasa Arab dan psikolinguistik mempunyai relevansi yang harmonis. Eksistensi psikolinguistik dapat diaktualisasikan dalam metodologi pembelajaran bahasa Arab. ${ }^{8}$ Adapun dalam perspektif Hasan, signifikansi psikolinguistik dan bahasa Arab terlihat saat bagaimana seorang guru mengkaji permasalahan yang melingkupi tindak berbahasa siswa dan pembelajarannya, serta bagaimana solusi yang paling solutif yang bisa ditawarkan. ${ }^{9}$ Berdasarkan hal tersebut, meminjam teori psikolinguitik sebagai basis pengembangan metodologi

5 Muhbib Abdul Wahab, "Pembelajaran Bahasa Arab Postmetode" 'Arabiyat: Jurnal Pendidikan Bahasa Arab dan Kebahasaaraban, 2, (1), 2015, h. 60.

${ }^{6}$ Buhori, "Peran Psikolinguistik Dalam Pembelajaran Bahasa Arab" Jurnal: Al-astar, Vol. V, Nomor. I, 2017, h. 60.

7 Ahmad Habibi Syahid, Bahasa Arab Sebagai Bahasa Kedua "Kajian Teoritis Pemerolehan Bahasa Arab Pada Siswa Non-Native" Jurnal: Arabiyat, Vol. 2, No. 1, 2015, h. 87.

8 Zulhannan, "Bahasa Arab dan Psikolinguistik: Kajian Konseptual dan Harmonis" Jurnal: Al-Bayan, Vol, 9, No. 2, 2017, h. 101.

9 Hasan Hasan, "Psikolinguistik: Urgensi dan Manfaatnya Pada Program Studi Pendidikan Bahasa Arab" Jurnal: Al-Mi'yar, Vol. 1, No. 2, 2018, h. 17. 
Muhammad Yusuf: Psikolinguistik Dalam Metodologi Pembelajaran Bahasa Arab Di Era Postmetode

pembelajaran merupakan salah satu pra-syarat yang bisa dipilih untuk masuk dalam trend postmetode.

Bertitik tolak dari latar belakang di atas, agaknya menjadi penting untuk menawarkan konsep metodologi bahasa Arab di era postmetode dengan berdasar pada pembacaan terhadap teori psikolinguistik, khususnya teori dalam pemerolehan bahasa. Kajian ini secara naratif penulis deskripsikan dengan "Psikolinguistik Dalam Metodologi Pembelajaran Bahasa Arab Di Era Postmetode".

\section{METODE PENELITIAN}

Tulisan ini bertujuan untuk mendiskusikan permasalahan penting dan menarik, yaitu Psikolinguistik Dalam Metodologi Pembelajaran Bahasa Arab di Era Postmetode. Tulisan ini mengandalkan sumber bibliografis berupa buku dan artikel yang berada dijurnal ilmiah yang berkaitan dengan pokok permasalahan. Pembacaan data pemikiran para akademisi dengan menggunakan pendekatan kritis dan pemaknaan substansinya dengan analisis isi (content analysis).10 Asumsi dari kajian ini berangkat dari pemikiran Wahab yang berpendapat bahwa bahasa Arab telah memasuki era postmetode. Paradigma ini menghendaki profesionalitas para akademisi bahasa Arab dalam mensintesa sejumlah metode dan media, sehingga pembelajaran bahasa Arab lebih dapat dioptimalkan. ${ }^{11}$ Sintesis para ahli tersebut harus diawali dengan pembacaan akademik yang komprehensif. Dalam hal ini, penulis menggunakan psikolinguistik sebagai dasar dalam mengambil sintesis sejumlah metode dan media dalam pembelajaran bahasa Arab.

\section{PSIKOLINGUISTIK}

Secara etimologi, kata psikolinguistik terbentuk dari kata psikologi dan linguistik yang merupakan dua rumpun keilmuan yang berbeda baik secara prosedur ataupun metode keilmuannya. Dalam objek materialnya linguistik

10 Content analysis adalah telaah sistematik untuk menganalisis isi pesan dan mengolah pesan atas catatan-catatan atau dokumen sebagai sumber data, sehingga diperoleh suatu hasil atau pemahaman terhadap berbagai isi pesan komunikasi yang disampaikan secara terbuka, obyektif dan sistematik. Lihat Dalam Sanapiah Faisal, Metodologi Penelitian Pendidikan (Surabaya: Usaha Nasional, 1982), h. 133.

11 Muhbib Abdul Wahab, Pembelajaran Bahasa Arab Postmetode, ..... h. 67. 
Muhammad Yusuf: Psikolinguistik Dalam Metodologi Pembelajaran Bahasa Arab Di Era Postmetode

mengkaji struktur bahasa, sedangkan psikologi mengkaji perilaku berbahasa atau proses berbahasa. Kendati demikian, keduanya sama-sama mengkaji bahasa sebagai objek formalnya.

Secara historis integrasi dua rumpun keilmuan ini pada awalnya disebut dengan linguistik psychology. Setelah beberapa waktu, barulah ditemukan konsep pengintegrasian yang lebih sistematis yang kemudian memunculkan terma psikolinguistik. Istilah ini baru terlahir pada tahun 1954, yaitu saat terbitnya buku yang ditulis oleh Charles E. Osgood dan Thomas A. Seboek di Amerika Serikat.

Adapun secara terminologis, psikolinguistik merupakan disiplin keilmuan yang menjelaskan hakikat struktur bahasa, bagaimana genelogisnya, bagaimana pemerolehannya, dan bagaimana mengekspresikannya secara praktis. ${ }^{12}$ Dalam narasi yang lain, Dardjowidjojo berpendapat bahwa psikolinguistik adalah ilmu yang mempelajari proses mental yang dilalui oleh manusia dalam berbahasa. ${ }^{13}$ Berdasarkan pengertian di atas dapat diambil kesimpulan bahwa psikolinguistik merupakan disiplin keilmuan yang membahas tentang kebahasaan yang meliputi wilayah mekanistik (yang terdiri dari hakikat struktur bahasa, dan genealogisnya) dan juga wilayah mentalistik (bagaimana memperoleh bahasa, dan bagaimana mengekspresikannya secara praktis).

Dalam perspektif Chaer, ruang lingkup kajian psikolinguistik meliputi bagaimana esensi bahasa, bagaimana genealogis bahasa, bagaimana bahasa ibu diperoleh, bagaimana proses mental yang melingkupi kegiatan menyusun kalimat, bagaimana pertumbuhan dan gugurnya bahasa, bagaimana relasi antara bahasa dan konstruk berfikir, mengapa gangguan berbahasa itu muncul pada individu dan bagaimana cara menyembuhkannya, serta bagaimana sebaiknya bahasa itu dibelajarkan. ${ }^{14}$ Sementara dalam perspektif Dardjowidjojo, objek kajian psikolinguistik terdiri dari :a) komprehensi, yaitu proses mental yang dilalui oleh manusia sehingga mereka dapat menangkap

12 Abdul Chaer, Psikolinguistik Kajian Teoritik (Jakarta: PT Rineka Cipta, 2009), h. 5-6.

13 Soenjono Dardjowidjojo, Psikolinguistik Pengantar Pemahaman Bahasa Manusia (Jakarta: Yayasan Pustaka Obor, 2014), h. 7.

${ }^{14}$ Abdul Chaer, Psikolinguistik Kajian Teoritik..... h. 8-9. 
Muhammad Yusuf: Psikolinguistik Dalam Metodologi Pembelajaran Bahasa Arab Di Era Postmetode

apa yang dikatakan orang dan memahami apa yang dimaksud, b) produksi, yaitu proses mental pada diri manusia yang membuatnya dapat berujar, c) landasan biologis serta neurologis yang membuat manusia bisa berbahasa, d) pemerolehan bahasa, yaitu bagaimana anak memperoleh bahasa mereka. ${ }^{15}$ Berdasarkan hal tersebut dapat disimpulkan bahwa secara sederhana ruang lingkup kajian psikolinguistik terdiri dari proses mekanisitik dan mentalistik dalam bahasa.

Dalam konteks pembelajaran bahasa, terdapat dua madzhab besar yang melingkupinya, yaitu madzhab behaviorisme dan kognitivisme. Secara umum, tidak ada perbedaan yang signifikan antara kedua madzhab ini dalam prosedur pemerolehan bahasa. Perbedaan yang mendasar hanya terletak pada interpretasi tahap pemerolehan, dan faktor yang mendominasi dalam mengakuisisi bahasa anak. Keragaman tersebut sebagai hasil dari perbedaan pendekatan dan persepsi ahli dalam melihat sifat bahasa. ${ }^{16}$

\section{A. Teori Behaviorisme}

Behaviorisme ${ }^{17}$ adalah suatu aliran psikologi yang materi kajiannya adalah perilaku yang tidak berhubungan dengan kesadaran atau konstruk mental. ${ }^{18}$ Lebih lanjut Douglas Brown berpendapat, bahwa pendekatan behavioristik berfokus pada aspek-aspek yang bisa ditangkap langsung dari perilaku linguistik-respons yang bisa diamati secara nyata, serta berbagai hubungan antara respon dan peristiwa di

15 Soenjono Dardjowidjojo, Psikolinguistik Pengantar Pemahaman Bahasa Manusia...., h. 7.

16 Abdul Aziz Ibnu Ibrahim, 'Ilmu al Lugoh al Nafsi (Riyadh: Jami'ah al-Imam Muhammad Ibnu Syu'ud al-Islamiyah, 2006), h. 245.

17 Secara historis, teori ini muncul pada akhir abad 19. Teori ini dimulai oleh langkah Pavlov (1849-1936 M) mengamati air liur anjing yang keluar ketika diberi makanan. Pemberian makanan ini dilakukan berkali-kali. Lalu, Pavlov berkesimpulan bahwa makanan adalah stimulus (rangsangan) bagi anjing, yang diikuti secara spontan oleh respons. Respons itu berupa air liur yang keluar ketika anjing melihat makanan. Ketika anjing itu melihat pembantu datang lagi, padahal ia tidak membawa makanan, air liurnya tetap keluar. Itu bisa diasumsikan bahwa anjing menyamakan kedatangan pembantu dengan keberadaan makanan. Dengan kata lain, anjing memahami bahwa pembantu datang berarti makanan muncul. Lihat dalam Jaelani Musni, Psikolinguistik Pembelajaran Bahasa Arab (Bandung: Humaniora, 2009), h. 18.

18 Nazri Syakur, Proses Psikologi Dalam Pemerolehan Bahasa (Yogyakarta: Bidang Akademik UIN Sunan Kalijaga, 2008), h. 25. 
Muhammad Yusuf: Psikolinguistik Dalam Metodologi Pembelajaran Bahasa Arab Di Era Postmetode

sekitar mereka. Seorang behavioris memandang perilaku bahasa yang efektif sebagai wujud tanggapan yang tepat terhadap stimuli. Jika sebuah respons tertentu dirangsang berulang-ulang, ia lantas menjadi kebiasaan, atau terkondisikan. Oleh karenanya, anak-anak menghasilkan respons linguistik yang memang dikondisikan. ${ }^{19}$

Dalam perspektif Syakur (2008) pemerolehan bahasa ${ }^{20}$ terkait dengan penguasaan tak sadar terhadap suatu bahasa yang umumnya terjadi pada anak-anak terhadap bahasa pertamanya. Sementara penguasaan bahasa yang dilakukan secara sadar dinamakan dengan belajar. Lebih lanjut Syakur menjelaskan, bahwa penguasaan secara sadar biasanya dilakukan untuk menguasai bahasa kedua. Adapun teori tentang pemerolehan bahasa dalam perspektif behavioristik diantaranya adalah teori tabularasa ${ }^{21}$ dan teori perilaku verbal.

Dalam konteks belajar bahasa, kaum behavior membaginya menjadi dua, yaitu teori belajar tanpa penguatan atau tipe S (S-R) seperti teori belajar pengkondisian klasik oleh Pavlov dan teori belajar berpenguat atau tipe $\mathrm{R}$ (S-R-R) seperti pengkondisian instrumental oleh Throndinke dan pengkondisian operan oleh Skinner. ${ }^{22}$

19 Douglas Brown, Prinsip Pembelajaran dan Pengajaran Bahasa (Jakarta: Dubes Amerika Serikat Di Indonesia, 2008), h. 28-29.

20 Dalam perspektif Mamluatul Hasanah (2010), pemerolehan bahasa merupakan suatu pengkajian, bagaimana seorang manusia itu memperoleh bahasa, baik pada tataran semantik, sintaksis, morfologis, maupun fonologi. Dalam versi psikolinguistik, seseorang berbahasa dalam dua tahap, reseptif dan produktif. Lihat penjelasan lebih lanjut dalam Mamluatul Hasanah, Proses Manusia Berbahasa "Perspektif al-Qur'an dan Psikolinguistik" (Malang: UIN-Maliki Press, 2010), h. 31.

21 Tabularasa secara etimologi berarti kertas kosong, dalam arti belum ditulisi apaapa. Teori tabularasa merupakan pandangan behavioristik yang mengklaim bahwa anak-anak memasuki dunia nyata dengan suatu tabula rasa, suatu batu tulis kosong yang tidak mengandung nosi-nosi bawaan tentang dunia atau tentang bahasa. Kemudian anak-anak ini dibentuk oleh lingkungan mereka dan secara lamban terkondisikan melalui beragama skedul penguatan. Menurut teori ini semua pengetahuan manusia yang nampak di dalam perilaku berbahasanya merupakan hasil perpaduan peristiwa-peristiwa linguistik yang dialami dan diamati olehnya. Istilah dialami dan diamati mengindikasikan bahwa apa yang tidak dialami atau diamati tidak akan pernah menjadi bagian dari pengetahuan linguistik seseorang. Lihat dalam Nazri Syakur, Proses Psikologi Dalam Pemerolehan Bahasa, ...., h. 28.

22 Nazri Syakur, Proses Psikologi....., h. 39-40. 
Muhammad Yusuf: Psikolinguistik Dalam Metodologi Pembelajaran Bahasa Arab Di Era Postmetode

\section{B. Teori Kognitivisme}

Dalam perspektif kaum kognitivisme, teori pemerolehan bahasa yang dikemukakan oleh kaum behaviorisme belum memadai untuk menerangkan proses pemerolehan bahasa oleh anak-anak, khususnya yang terkait dengan kreatifitas berbahasa. Dimana hasil analisis kaum behaviorisme tidak menjelaskan kompetensi linguistik (pengetahuan tata bahasa) yang telah diinternalisasi oleh anak-anak dan disimpan dalam otaknya, serta bagaimana kompetensi tersebut digunakan untuk membuat dan memahami kalimat-kalimat baru yang belum pernah dibuatnya. ${ }^{23}$ Pada akhirnya, kritik tersebut melahirkan teori baru dalam permerolehan bahasa yang disebut dengan teori nativis atau teori bawaan (innateness).

Dalam perspektif kaum nativis manusia lahir dilengkapi oleh suatu alat yang memungkinkannya dapat menguasai bahasa dengan mudah dan cepat. Dalam narasi Chomsky (1970) sebagaimana dikutip Syakur (2008), alat bahasa tersebut merupakan properti yang tersimpan di dalam suatu kotak hitam kecil yang dibawa anak-anak sejak lahir, yang disebut dengan "alat pemerolehan bahasa" atau language acquitision device (LAD). ${ }^{24}$ Alat inilah yang menyebabkan anak memiliki kemampuan untuk membuat hipotesis tentang struktur bahasa secara umum, dan tentang struktur bahasa yang sedang dipelajari secara khsuus. ${ }^{25}$

Dalam konteks belajar bahasa atau penguasaan bahasa secara sadar, teori yang ditelurkan oleh para kaum kognitivisme diantaranya adalah (teori Piaget), (teori Bruner) dan teori belajar pemrosesan informasi. Lebih lanjut, Syakur menjelaskan pembagian teori belajar bahasa dalam perspektif kaum kognitiv tersebut, yaitu: 1) teori piaget.

${ }^{23}$ Nazri Syakur, Proses Psikologi Dalam Pemerolehan Bahasa, ...., h. 86.

${ }^{24}$ McNeil (1966) mendeskripsikan LAD sebagai alat yang terdiri dari empat properti bahasa bawaan, yaitu: 1) kemampuan membedakan bunyi-bunyi ujaran dari bunyi-bunyi lain yang ada pada lingkungan, 2) kemampuan mengatur data bahasa menjadi beragam kelas yang pada waktu berikutnya dapat dilakukan perbaikan-perbaikan, 3) hanya pengetahuan tentang sistem bahasa jenis tertentu yang mungkin, dan yang lain tidak mungkin 4) kemampuan melibatkan diri di dalam menilai pengembangan sistem bahasa secara terus menerus untuk membangun sistem bahasa sesederhana mungkin, terlepas dari masukan bahasa yang tersedia. 
Muhammad Yusuf: Psikolinguistik Dalam Metodologi Pembelajaran Bahasa Arab Di Era Postmetode

Dalam teori ini akan ditemukan istilah-istilah seperti konstruktivisme, kerangka rujukan atau skema, operasi, asimilasi, dan akomodasi. 2) teori Bruner. Belajar dalam perspektif Bruner adalah proses sosial yang aktif dimana siswa membangun pandangan atau konsep baru berbasis pengetahuan mereka yang telah ada sebelumnya. Para siswa memilih informasi, membentuk hipotesis, dan kemudian mengintegrasikan bahan baru ini ke pengetahuan lama dan konstruk mental mereka sendiri. Dengan kata lain, siswa secara aktif membangun pengetahuannya dengan menghubungkan informasi baru ke suatu kerangka rujukan psikologi yang diperoleh sebelumnya,26 3) Teori pemrosesan informasi. Fokus utama teori ini adalah ingatan, atau penyimpanan dan pemanggilan informasi. Terdapat beraneka pandangan mengenai teori ini, salah satunya McClelland yang berpendapat bahwa ingatan atau pemrosesan informasi tersebar paralel. Hal ini bisa dinarasikan bahwa semakin banyak hubungan-hubungan ke satu ide atau konsep, maka semakin banyak pula kemungkinan hal tersebut akan diingat. ${ }^{27}$

Eksplanasi dari kedua teori dalam pemerolehan dan belajar bahasa di atas dapat disederhanakan dalam terma naturalistik dan formalistik. Kaum behaviorisme beranggapan bahwa pembelajaran bahasa itu bersifat natural atau alamiah dalam lingkungan masyarakat. Sehingga berdasarkan teori ini, dalam konteks pembelajaran bahasa Arab di Indonesia, kaum akademisi mengupayakan untuk membentuk bi'ah lughowiyah. Sementara aliran kognitivisme berpendapat bahwa pembelajaran bahasa itu berada pada situasi formal di dalam kelas. ${ }^{28}$ Bentuk integralnya, pembelajaran bahasa yang berdasar pada teori ini membutuhkan kurikulum dalam proses pembelajaran bahasa Arab.

\section{METODOLOGI PEMBELAJARAN BAHASA ARAB DI ERA POSTMETODE}

Secara etimologis kata metodologi berakar dari bahasa Yunani yang merupakan integrasi antara kata metodos yang berarti jalan, cara, sistem, dan logos yang berarti ilmu atau pengetahuan. Adapun secara terminologis

${ }^{28}$ Sarwadi, Kontroversi Nurture dan Nature Dalam Psikolinguistik (Jurnal: al-Tazkiah, Vol. 3 No. 1, 2013), h. 61. 
Muhammad Yusuf: Psikolinguistik Dalam Metodologi Pembelajaran Bahasa Arab Di Era Postmetode

metodologi berarti ilmu pengetahuan yang mempelajari tentang cara-cara atau jalan yang ditempuh untuk mencapai suatu tujuan dengan hasil yang efektif dan efisian. ${ }^{29}$ Dalam perspektif Edward Antony (1963), metodologi pembelajaran terdiri dari komponen prosedural yang meliputi pendekatan, metode, dan tekhik pembelajaran, dalam hal ini pembelajaran bahasa Arab.

\section{a. Pendekatan}

Pendekatan adalah asumsi teoritis yang berkaitan dengan hakikat bahasa, belajar bahasa, dan pengajaran bahasa. ${ }^{30}$ Sementara itu, Acep Hermawan berpendapat bahwa pendekatan merupakan tingkat pendirian filosofis mengenai bahasa, belajar, dan mengajar bahasa. Sedangkan al-Naqah berpendapat bahwa pendekatan pada hakikatnya merupakan sekumpulan asumsi tentang proses belajar mengajar yang bersifat aksiomatis. ${ }^{31}$ Berdasarkan beberapa pengertian di atas dapat diambil sintesa bahwa pendekatan merupakan seperangkat asumsi teoritis bersifat aksiomatis yang berangkat dari pemikiran filosofis seseorang berkaitan dengan hakikat bahasa, belajar bahasa, dan mengajar bahasa.

Richard dan Rodger berpendapat bahwa secara garis besar terdapat tiga madzhab berkaitan dengan pendekatan dalam pembelajaran bahasa ini, yaitu madzhab strukturalis, fungsionalis, dan interaksionalis. ${ }^{32}$ Madzhab strukturalis beranggapan bahwa bahasa terdiri dari beberapa unsur yang terintegrasi secara gramatikal. Sementara madzhab fungsionalis berpendapat bahwa hakikat bahasa merupakan media untuk berekspresi dalam tindak tutur yang pragmatis. Sedangkan madzhab interaksionalis beranggapan bahwa hakikat bahasa merupakan media untuk menciptkan hubungan sosial antar individu.

${ }^{29}$ Ahmad Izzan, Metodologi Pembelajaran Bahasa Arab (Bandung: Humaniora, 2009), h. 72 .

30 Pranowo, Teori Belajar Bahasa (Yogyakarta: Pustaka Pelajar, 2015), h. 259.

${ }^{31}$ Acep Hermawan, Metodologi Pembelajaran Bahasa Arab (Bandung: PT Remaja Rosdakarya, 2011), h. 167.

32 Aziz Fahrurrozi, Pembelajaran Bahasa Arab: Problematika dan Solusinya Jurnal: Arabiyat, Vol 1, No. 2, 2014, h. 166. 
Muhammad Yusuf: Psikolinguistik Dalam Metodologi Pembelajaran Bahasa Arab Di Era Postmetode

\section{b. Metode}

Pranowo berpendapat bahwa metode adalah rancang bangun pembelajaran yang satu sama lain tidak saling bertentangan untuk mencapai suatu tujuan. ${ }^{33}$ Lebih lanjut, Hermawan mengungkapkan bahwa metode pada dasarnya adalah tingkat perencanaan program yang bersifat menyeluruh yang berhubungan erat dengan langkah-langkah penyampaian materi secara prosedural, tidak saling bertentangan, dan tidak bertentangan dengan pendekatan. ${ }^{34}$ Berangkat dari pengertian di atas dapat diambil kesimpulan bahwa metode merupakan desaign operasional pembelajaran secara menyeluruh yang masih berapa pada level perencaan yang dibuat berdasarkan pendekatan pembelajaran yang terintegrasi dengan tahap operasional penyampaian materi pembelajaran.

Dalam setiap pembelajaran bahasa, sudah barang tentu seorang guru bisa memilih dari beraneka metode yang ada. Namun, guru yang memiliki kompetensi pedagogik dan profesional pasti mampu memilih metode yang kompatible untuk diaplikasikan dalam sebuah pembelajaran, sehingga proses pembelajaran dapat berjalan efektif dan efesien.

\section{c. Tekhnik}

Tekhnik pembelajaran merupakan praktik seni yang sangat tergantung kepada pendidik dan kompetensinya dalam mengelola kelas. Tekhnik pembelajaran tentu berbeda pada setiap kondisi pembelajaran yang ada, bahkan dikatakan dalam kondisi yang sama pun akan terjadi perbedaan. Dengan demikian tekhnik pembelajaran adalah aktivitas spesifik yang diimplementasikan dalam ruang belajar yang relevan dengan metode dan pendekatan yang telah ditentukan. ${ }^{35}$ Berdasarkan pengertian di atas dapat diasumsikan bahwasannya tekhnik

33 Pranowo, Teori Belajar Bahasa, ..... h. 265

${ }^{34}$ Acep Hermawan, Metodologi Pembelajaran Bahasa Arab, ..... h. 168.

35 Fathur Rohman, Metodologi Pembelajaran Bahasa Arab (Malang: Madani, 2015), h. 260. 
Muhammad Yusuf: Psikolinguistik Dalam Metodologi Pembelajaran Bahasa Arab Di Era Postmetode

pembelajaran merupakan pertunjukan seni oleh seorang guru dengan menjadikan proses pembelajaran di kelas sebagai panggung dengan mengacu kepada pendekatan dan metode yang telah mendahului dalam tahap perencanaan agar proses pembelajaran dapat berjalan kondusif, efektif, dan efesien.

Berdasarkan penjabaran di atas, dapat diasumsikan bahwasannya ketiga komponen dalam metodologi pembelajaran bahasa Arab terintegrasi secara hirarkis. Konkritnya, sebuah pendekatan akan memaksa seorang guru untuk memformulasikan metode, dan metode pada gilirannya juga akan memaksa seorang guru untuk mengaplikasikan teknik pembelajaran dalam proses pembelajaran di kelas. Oleh karenanya dapat dikatakan bahwa pendekatan itu bersifat abstrak dan aksiomatis, sementara metode bersifat konkrit dan prosedural dalam level perencanaan, sedangkan tekhnik bersifat operasional pada level realitas pembelajaran di kelas.

Dalam konteks postmetode, metodologi pembelajaran sedikit berbeda dengan era metode. Dalam konteks ini metodologi tidak hanya berhenti pada cara pandang terhadap hakikat bahasa, mengajar bahasa, dan belajar bahasa. Namun sudut pandang yang mendasari rumusan metodologi tersebut lebih luas. Mencakup berbagi bidang keilmuan. Seperti perspektif psikolinguistik, sosiolinguistik, ataupun antropolinguistik. ${ }^{36}$ Berdasarkan hal ini, dapat dikatakan bahwa metodologi pembelajaran bahasa Arab sudah lebih demokratis dan tidak terlalu mementingkan konsep hirarki pendekatan, metode, dan tekhnik ala Edward Antony. Sebagai konsekuensi dari konsep ini, seorang guru dituntut untuk memiliki kompetensi yang adaptable dalam proses pembelajaran. Kompetensi tersebut pada gilirannya akan berdaya guna untuk membaca fenomena di lapangan berkaitan dengan proses pembelajaran bahasa Arab. 37

Berdasarkan beberapa kriteria di atas dapat dikatakan bahwa metodologi pembelajaran bahasa Arab di era postmetode merupakan sebuah pengetahuan tentang bagaimana seorang guru membelajarkan bahasa Arab dengan berdasar pada pembacaan akademik yang multi-perspektif. Berangkat

\footnotetext{
${ }^{36}$ Muhbib Abdul Wahab, Pembelajaran Bahasa Arab Postmetode....., h. 60.

37 Muhbib Abdul Wahab, Pembelajaran Bahasa Arab Postmetode......, h. 68.
} 
Muhammad Yusuf: Psikolinguistik Dalam Metodologi Pembelajaran Bahasa Arab Di Era Postmetode

dari terminologi ini, seorang guru tidak dituntut untuk terpaku pada satu pendekatan, metode, ataupun suatu tekhnik dalam membelajarkan bahasa Arab. Dimana konsep hirarki tersebut berpotensi besar membatasi ruang gerak guru dalam mengembangkan pembelajaran bahasa Arab pada kondisi yang senyatanya terjadi dalam proses pembelajaran di kelas.

\section{PSIKOLINGUISTIK DALAM METODOLOGI PEMBELAJARAN BAHASA ARAB DI ERA POSTMETODE}

Tidak seperti pada era metode yang cenderung mendewakan sistem hirarki ala Antony, yang secara tidak langsung membatasi ruang gerak guru untuk berimprovisasi. Postmetode memberikan kebebasan kepada seorang guru untuk mengembangkan proses pembelajaran bahasa Arab di kelas. Pengembangan pembelajaran tersebut tentu saja berdasarkan pembacaan akademik yang dilakukan oleh seorang guru.

Psikolinguistik dalam metodologi pembelajaran bahasa Arab di era postmetode dapat dijadikan pondasi untuk mengembangkan proses pembelajaran di kelas, sehingga tercipta pembelajaran yang kondusif. Secara fungsional, psikolinguistik berperan sebagai alat identifikasi dalam menseleksi materi yang sesuai dengan tahap perkembangan mental siswa. Selanjutnya bagaimana cara membelajarkan materi pembelajaran bahasa Arab tersebut sesuai dengan tahap perkembangan psikologi siswa. Lebih lanjut, dalam era postmetode, integritas seorang guru menjadi harga yang tidak bisa ditawar lagi, mengingat perannya yang sangat strategis dalam proses pembelajaran. Peran tersebut berkaitan dengan bagaimana seni seorang guru mendayagunakan proses pembelajaran bahasa Arab di kelas.

Disiplin ilmu psikolinguistik ini telah berperan dalam memberikan warna baru dalam proses pembelajaran bahasa Arab. Secara konkrit, disiplin keilmuan tersebut telah melahirkan model-model pembelajaran bahasa Arab yang meliputi model pembelajaran aktif, model pembelajaran koopertatif, dan model pembelajaran pakem. Model pembelajaran bahasa Arab tersebut tentu saja didahului oleh pembacaan akademik dari seorang guru dengan berdasar pada disiplin psikolinguistik. Identifikasi terhadap proses pembelajaran berdasar teori psikolinguistik merupakan prasyarat untuk bisa mengaplikasikan model-model pembelajaran bahasa Arab ini secara efektif dan efesien. Sehingga bila dinarasikan, bentuk identifikasi tersebut secara 
Muhammad Yusuf: Psikolinguistik Dalam Metodologi Pembelajaran Bahasa Arab Di Era Postmetode

sederhana yaitu; bagaimana materi pembelajaran bahasa yang sesuai, bagaimana membelajarkan materi agar menarik minat siswa, dan apakah ada permasalahan pada siswa secara neurologis, bagaiamana formula pembelajaran yang ramah terhadap sistem kerja otak siswa ${ }^{38}$, dan seterusnya.

\section{A. Pembelajaran Aktif}

Pembelajaran aktif (active learning) dimaksudkan untuk mengoptimalkan penggunaan semua potensi yang dimiliki oleh anak didik, sehingga semua anak didik dapat mencapai hasil belajar yang memuaskan sesuai dengan karakteristik pribadi yang mereka miliki. Disamping itu, pembelajaran aktif (active learning) juga dimaksudkan untuk menjaga perhatian siswa agar tertuju pada proses pembelajaran. Lebih lanjut Umi Mahmudah dan Abdul Wahab Rasyidi menjelaskan bahwa pembelajaran aktif merupakan segala bentuk pembelajaran yang memungkinkan siswa berperan secara aktif dalam proses pembelajaran itu sendiri baik dalam bentuk interaksi dengan sesama siswa maupun siswa dengan pengajar dalam proses pembelajaran tersebut. ${ }^{39}$

\section{B. Pembelajaran Kooperatif}

Menurut Brown, pembelajaran kooperatif merupakan belajar dengan satu atau lebih teman untuk mendapatkan umpan balik, mengumpulkan informasi, atau merancang aktivitas bahasa. ${ }^{40}$ Umi Mahmudah dan Abdul Wahab Rasyidi mendeskripsikan pembelajaran kooperatif sebagaimana berikut:

1. Jigsaw

Secara operasional, model ini mengelompokkan siswa kedalam tim yang beranggotakan lima-enam siswa yang mempelajari materi pelajaran yang telah dibagi menjadi beberapa sub-bab. Misalnya, materi tentang isim. Materi ini bisa dibagi

38 Sistem kerja otak juga mempunyai signifikansi yang tinggi dengan bahasa. Lihat dalam Wahyudi dan Muhammad Ridha, "Urgensi Mempelajari Psikolinguistik Pada Pembelajaran Bahasa" Jurnal: Islamika, Vol. 17, No. 1, 2017, h. 124. Dalam disiplin keilmuan sistem kerja otak masuk dalam kajian neurologi. Integrasi antara ilmu otak dan bahasa ini pada akhirnya menghasilkan disiplin ilmu neurolinguistik.

39 Wahyudi dan Muhammad Ridha, "Urgensi Mempelajari....., h. 63-64.

40 Douglas Brown, Prinsip Pembelajaran dan Pengajaran Bahasa (Jakarta: Kedubes Amerika Serikat, 2008), h. 146. 
Muhammad Yusuf: Psikolinguistik Dalam Metodologi Pembelajaran Bahasa Arab Di Era Postmetode

menjadi pengertiannya, karakteristiknya, pembagiannya, unsur filosofisnya, dsb. Setiap anggota tim membaca sub-bab yang ditugaskan. Kemudian, anggota tim yang berbeda yang mempelajari sub-bab yang sama bertemu untuk berdiskusi. Setelah itu, mereka kembali ke tim mereka, dan mempresentasikan subbab yang telah mereka diskusikan sebelumnya. ${ }^{41}$

2. Learning together

Model ini melibatkan siswa yang bekerja dalam kelompokkelompok yang beranggotakan empat atau lebih siswa dengan tugas tertentu. Kelompok itu menyerahkan hasil tugas dan menerima umpan balik. Model ini menekankan pembinaan kerjasama tim sebelum siswa mulai bekerja sama dan melakukan diskusi terjadwal di dalam kelompok. ${ }^{42}$

\section{Pakem}

Pakem merupakan akronim dari pembelajaran aktif, kreatif, efektif, dan menyenangkan. Aktif dimaksudkan bahwa dalam proses pembelajaran guru harus menciptakan suasana sedemikian rupa sehingga siswa aktif bertanya, mempertanyakan, dan mengemukakan gagasan. Peran aktif dari siswa sangat penting dalam rangka pembentukan generasi yang kreatif, yang mampu menghasilkan sesuatu untuk kepentingan dirinya dan orang lain. Kreatif juga dimaksudkan agar guru menciptakan kegiatan belajar yang beragam sehingga memenuhi berbagai tingkat kemampuan siswa. Menyenangkan adalah suasana belajar-mengajar yang menyenangkan sehingga siswa memusatkan perhatiannya secara penuh pada belajar sehingga waktu curah perhatiaannya tinggi. 43

Ragam model pembelajaran bahasa Arab di atas akan berperan secara optimal bila seorang guru mampu berperan sebagaimana mestinya. Dalam tahap awal, seorang guru dituntut untuk mendialogkan teori psikolinguistik dengan fenomena yang ada, dalam hal ini proses pembelajaran bahasa Arab yang senyatanya terjadi dalam kelas. Dengan disiplin psikolinguistik, guru

41 Umi Mahmudah dan Abdul Wahab, Active Learning Pembelajaran Bahasa Arab (Malang: UIN-Maliki Press, 2008), h. 85.

42 Umi Mahmudah dan Abdul Wahab, Active Learning ......, h. 86.

43 Umi Mahmudah dan Abdul Wahab, Active Learning ......, h. 87. 
Muhammad Yusuf: Psikolinguistik Dalam Metodologi Pembelajaran Bahasa Arab Di Era Postmetode

mampu mengidentifikasi materi bahasa Arab yang sesuai dengan siswa, bagaimana membelajarkannya sehingga tercipta situasi yang kondusif dan harmonis, bahkan seorang guru mampu mengidentifikasi bila terdapat kelainan pada diri siswa secara neurologis. Bila prasyarat ini kemudian tidak dipenuhi oleh seorang guru, model pembelajaran ini tidak akan berjalan optimal.

Melihat begitu vital peran dari seorang guru di era postmetode, maka ia dituntut untuk mempunyai berbagai kompetensi yang membantu tercapainya proses pembelajaran bahasa Arab yang efektif dan efesien. Kompetensi tersebut antara lain:

1. Kompetensi pribadi

Secara kodrati seorang guru harus menguasai pengetahuan yang akan diajarkannya kepada siswa secara benar dan bertanggung jawab. Ia juga harus memiliki pengetahuan penunjang tentang kondisi fisiologis, psikologis, dan pedagogis dari peserta didik yang dihadapinya. ${ }^{4}$

2. Kompetensi sosial

Berdasarkan kodrat manusia sebagai makhluk sosial, seorang guru harus dapat memperlakukan siswa secara wajar dan bertujuan agar tercapai optimalisasi potensi pada diri masing-masing siswa. Guru harus memahami dan menerapkan prinsip belajar humanistik yang beranggapan bahwa keberhasilan belajar ditentukan oleh kemampuan belajar yang ada pada siswa tersebut. Adapun kompetensi sosial yang harus dimiliki seorang guru adalah menyangkut kemampuan berkomunikasi dengan siswa dan lingkungan mereka, seperti orang tua dan sesama teman. ${ }^{45}$

3. Kompetensi profesional

Berdasarkan peran guru sebagai pengelola proses pembelajaran, maka ia dituntut untuk memiliki kemampuan profesional yang setidaknya terdiri dari beberapa poin, yaitu: kemampuan dalam merencanakan sistem pembelajaran, kemampuan dalam melakukan sistem pembelajaran, kemampuan dalam mengevaluasi sistem

\footnotetext{
${ }^{44}$ Umi Mahmudah dan Abdul Wahab, Active Learning ......, h. 13.

45 Umi Mahmudah dan Abdul Wahab, Active Learning ......, h. 14.
} 
Muhammad Yusuf: Psikolinguistik Dalam Metodologi Pembelajaran Bahasa Arab Di Era Postmetode

pembelajaran, dan kemampuan dalam mengembangakan sistem pembelajaran. ${ }^{46}$

\section{SIMPULAN}

Dalam konteks postmetode, metodologi tidak hanya terpaku pada konsep hirarki seperti pada era metode. Pada era postmetode, metodologi dituntut sebagai hasil pembacaan akademik dari berbagai perspektif keilmuan, salah satunya disiplin keilmuan psikolinguistik. Dengan berdasar pada psikolinguistik, metodologi pembelajaran bahasa Arab menghasilkan beraneka model dalam pembelajaran, yaitu active learning, cooperatif learning, dan pakem. Model pembelajaran tersebut merupakan sintesis akademisi dari beragam metode yang ada. Sintesis tersebut didasarkan pada pembacaan akademik dengan meminjam teori psikolinguistik sebagai pisau analisis. Secara sederhana, pisau analisis tersebut bisa dinarasikan: apa saja materi dalam pembelajaran bahasa Arab, bagaimana memilih materi kebahasa Araban yang sesuai dengan minat dan kebutuhan siswa, bagaimana cara yang efektif dan efesien dalam membelajarkan materi, apakah ada permasalahan dalam diri siswa secara neurologis, bagaimana solusi yang bisa ditawarkan bila ditemukan permasalahan yang terjadi dalam proses pembelajaran, dan seterusnya. Lebih lanjut, dalam era ini, posisi guru lebih penting dalam proses pembelajaran. Karena ia dengan segala perannya dalam proses pembelajaran diharapkan dapat memandu proses pembelajaran bahasa Arab agar berjalan dengan optimal. Oleh karenanya, guru dituntut untuk memiliki setidaknya kompetensi pribadi, kompetensi sosial, dan kompetensi profesional.

\section{DAFTAR PUSTAKA}

Brown, Douglas. Prinsip Pembelajaran dan Pengajaran Bahasa. Jakarta: Dubes Amerika Serikat Di Indonesia. 2008.

Buhori. "Peran Psikolinguistik Dalam Pembelajaran Bahasa Arab" Jurnal: Alastar, Vol. V, Nomor. I, 2017.

Chaer, Abdul. Psikolinguistik "Kajian Teoritik". Jakarta: PT Rineka Cipta, 2009.

46 Umi Mahmudah dan Abdul Wahab, Active Learning ....... h. 14-15. 
Muhammad Yusuf: Psikolinguistik Dalam Metodologi Pembelajaran Bahasa Arab Di Era Postmetode

Dardjowidjojo, Soenjono. Psikolinguistik "Pengantar Pemahaman Bahasa Manusia. Jakarta: Yayasan Pustaka Obor. 2014.

Fahrurrozi, Aziz. "Pembelajaran Bahasa Arab: Problematika dan Solusinya". Jurnal: Arabiyat, Vol 1, No. 2, 2014.

Faisal, Sanapiah. Metodologi Penelitian Pendidikan. Surabaya: Usaha Nasional. 1982.

Hasan, Hasan. "Psikolinguistik: Urgensi dan Manfaatnya Pada Program Studi Pendidikan Bahasa Arab" Jurnal: Al-Mi'yar, Vol. 1, No. 2, 2018. DOI 10.35931/am.v1i2.41

Hasanah, Mamluatul. Proses Manusia Berbahasa "Perspektif al-Qur'an dan Psikolinguistik". Malang: UIN-Maliki Press. 2010.

Hermawan, Acep. Metodologi Pembelajaran Bahasa Arab. Bandung: PT Remaja Rosdakarya. 2011.

Ibrahim, Abdul Aziz Ibnu. 'Ilmu al-Lugoh an-Nafsi. Riyadh: Jami'ah al-Imam Muhammad Ibnu Syu'ud al-Islamiyah. 2006.

Izzan, Ahmad. Metodologi Pembelajaran Bahasa Arab. Bandung: Humaniora, 2009.

Mahmudah, Umi dan Abdul Wahab. Active Learning Pembelajaran Bahasa Arab. Malang: UIN-Maliki Press. 2008.

Musni, Jaelani. Psikolinguistik Pembelajaran Bahasa Arab. Bandung: Humaniora. 2009.

Pranowo. Teori Belajar Bahasa. Yogyakarta: Pustaka Pelajar, 2015.

Rohman, Fathur. Metodologi Pembelajaran Bahasa Arab. Malang: Madani, 2015.

Sarwadi. Kontroversi Nurture dan Nature Dalam Psikolinguistik. Jurnal: alTazkiah, Vol. 3 No. 1. 2013.

Syahid, Ahmad Habibi. "Bahasa Arab Sebagai Bahasa Kedua "Kajian Teoritis Pemerolehan Bahasa Arab Pada Siswa Non-Native'”' Jurnal:Arabiyat, Vol. 2, No. 1, 2015.

Syakur, Nazri. Kognitivisme Dalam Metodologi Pembelajaran Bahasa. Yogyakarta: PT Pustaka Insan Madani. 2009.

Syakur, Nazri. Proses Psikologik dalam Pemerolehan dan Belajar Bahasa. Yogyakarta: Bidang Akademik UIN Sunan Kalijaga. 2008.

Wahab, Muhbib Abdul. Pembelajaran Bahasa Arab Postmetode. 'Arabiyat: Jurnal Pendidikan Bahasa Arab dan Kebahasaaraban, 2, (1). 2015. 
Muhammad Yusuf: Psikolinguistik Dalam Metodologi Pembelajaran Bahasa Arab Di Era Postmetode

Wahyudi dan Muhammad Ridha. "Urgensi Mempelajari Psikolinguistik Pada Pembelajaran Bahasa". Jurnal: Islamika, Vol. 17, No. 1, 2017.

Zulhannan. "Bahasa Arab dan Psikolinguistik: Kajian Konseptual dan Harmonis" Jurnal: Al-Bayan, Vol, 9, No. 2, 2017. 
Muhammad Yusuf: Psikolinguistik Dalam Metodologi Pembelajaran Bahasa Arab Di Era Postmetode 